\title{
Thallium intoxication with metallic skin discoloration
}

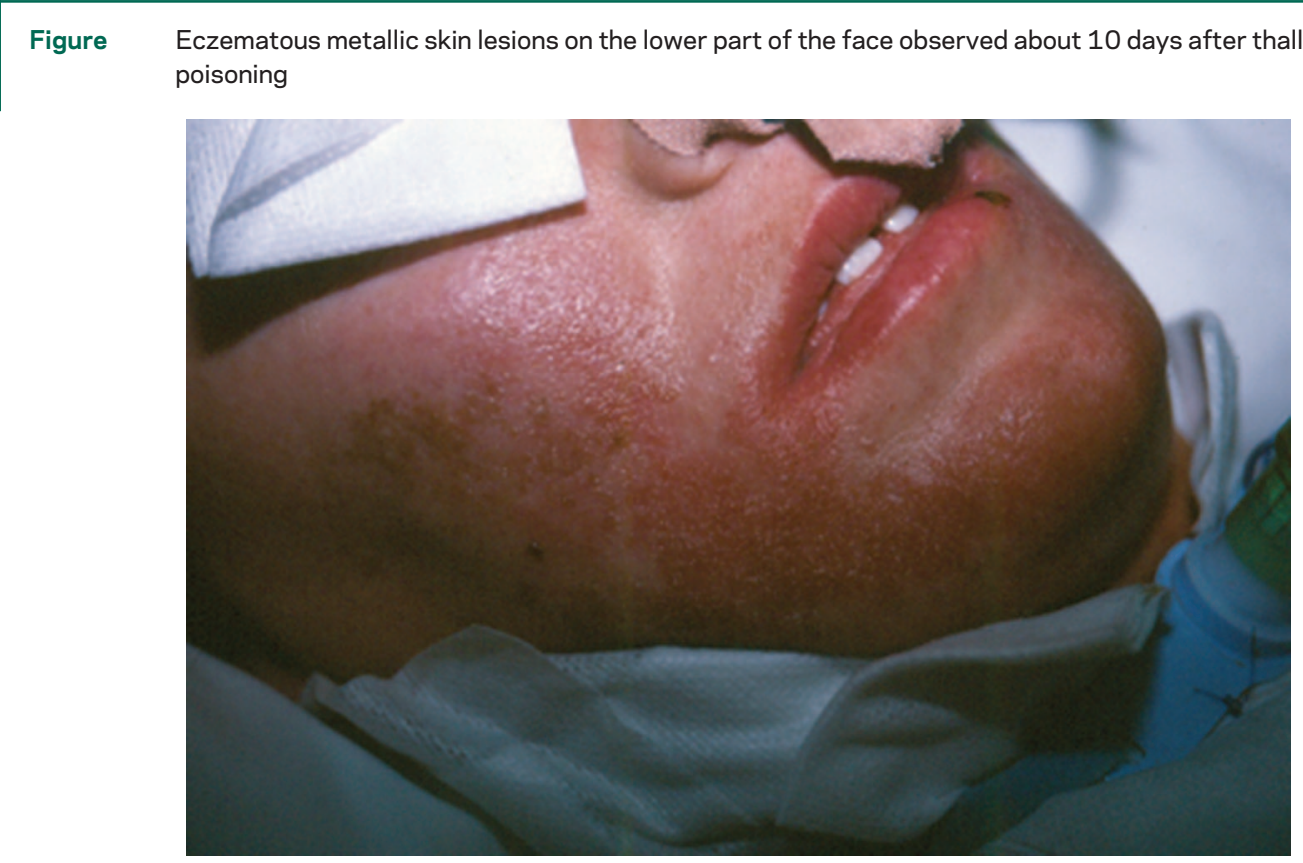

A 40-year-old woman was admitted to the hospital with painful paresthesias after drinking brandy and red wine containing thallium. A severe acute axonal sensorimotor neuropathy was diagnosed. She rapidly deteriorated and became comatose within less than a week. ${ }^{1}$ Metallic skin discoloration and darkening of the cheek and chin areas was observed (figure). Two weeks after thallium ingestion patchy hair loss was noted. She died from multiple organ failure after 25 days in the hospital.

Alopecia is the classic sign of thallium poisoning starting 2 to 4 weeks after ingestion. ${ }^{1}$ Skin changes precede hair loss and are an earlier diagnostic sign. ${ }^{2}$

The beverages contained large amounts of thallium sulfate and a former friend was later convicted of murder.

Jan O. Aasly, MD, PhD, Trondheim, Norway

Disclosure: The author reports no conflicts of interest.

Address correspondence and reprint requests to Dr. Jan O. Aasly, Department of Neurology, St. Olav's Hospital, Edvard Griegs gt. 8, N-7006 Trondheim, Norway; Jan.Aasly@ntnu.no

\section{REFERENCES}

1. Kuo HC, Huang CC, Tsai YT, Chu CC, Hsieh ST, Chu NS. Acute painful neuropathy in thallium poisoning. Neurology 2005;65:302-304.

2. Tromme I, Van Neste D, Dobbelaere F, et al. Skin signs in the diagnosis of thallium poisoning. Br J Dermatol 1998;138:321325. 


\title{
Neurology
}

\author{
Thallium intoxication with metallic skin discoloration \\ Jan O. Aasly \\ Neurology 2007;68;1869 \\ DOI 10.1212/01.wnl.0000266596.53985.8e
}

This information is current as of May 21, 2007

\section{Updated Information \& Services}

\section{References}

\section{Subspecialty Collections}

\section{Permissions \& Licensing}

Reprints including high resolution figures, can be found at: http://n.neurology.org/content/68/21/1869.full

This article cites 2 articles, 1 of which you can access for free at: http://n.neurology.org/content/68/21/1869.full\#ref-list-1

This article, along with others on similar topics, appears in the following collection(s):

All Imaging

http://n.neurology.org/cgi/collection/all_imaging

\section{Coma}

http://n.neurology.org/cgi/collection/coma

Forensic neurology

http://n.neurology.org/cgi/collection/forensic_neurology

Other toxicology

http://n.neurology.org/cgi/collection/other_toxicology

Peripheral neuropathy

http://n.neurology.org/cgi/collection/peripheral_neuropathy

Information about reproducing this article in parts (figures,tables) or in its entirety can be found online at:

http://www.neurology.org/about/about_the_journal\#permissions

Information about ordering reprints can be found online:

http://n.neurology.org/subscribers/advertise

Neurology ${ }^{\circledR}$ is the official journal of the American Academy of Neurology. Published continuously since 1951, it is now a weekly with 48 issues per year. Copyright . All rights reserved. Print ISSN: 0028-3878. Online ISSN: 1526-632X.

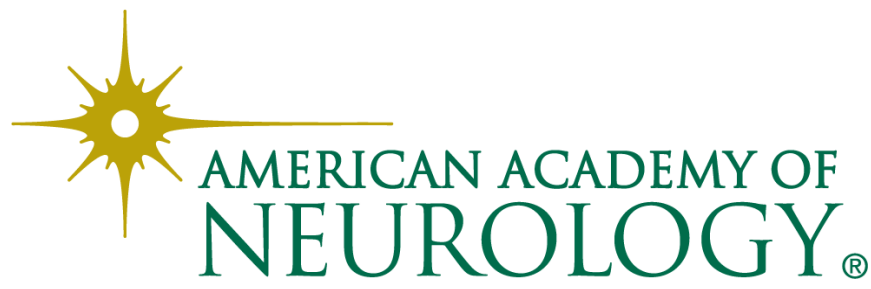

